\title{
UPAYA PEMBANGUNAN PENDIDIKAN POLITIK MELALUI PEMILIHAN BAGI MASYARAKAT PAPUA (STUDI PENERAPAN PENGGUNAAN NOKEN DALAM PEMILIHAN KEPALA DAERAH )
}

\author{
Nofi Sri Utami ${ }^{1}$ \\ Fakultas Hukum Universitas Islam Malang \\ Email1: noficy@gmail.com \\ Suratman ${ }^{2}$ \\ Fakultas Hukum Universitas Islam Malang \\ Email2: suratmanshmh@gmail.com \\ Arief Budiono ${ }^{3}$ \\ Universitas Muhammadiyah Surakarta \\ Corresponding Authors Emails: areevahims@gmail.com \\ DOI: https://doi.org/10.31764/jmk.v11i2.2721
}

Received: Augt 6, 2020, Accepted: Sept 3, 2020 /Published: Okt 31, 2020

\begin{abstract}
This research discusses presidential elections and legislatures, especially selecting regional heads in Papua using the Noken system. Furthermore, related to the form of political education through Noken for Papuans. Important to study, given that Papua is a region that has unique characteristics compared to other regions. This type of research uses doctrinal research, with a normative juridical approach. The choice of methods using deductive thinking patterns, the positivity paradigm, is then analyzed Prespriktif descriptively. This study is the first to apply the use of Noken in Papua in the Regional Head Election using two systems, namely Noken Bigmen and hanging Noken. Noken Bigmen means that all votes are submitted or represented to the customary chairman. Meanwhile, residents can see the agreement and the vote. Second, the form of political education through the Noken system's use is the deliberation in consensus to determine a leader. The people fully believe in the chief of the tribe, who is a candidate who is considered acceptable and worthy of election. The consensus is the fourth incarnation of Pancasila.
\end{abstract}

Keywords: noken; Papua; political education.

\begin{abstract}
ABSTRAK
Penelitian ini membahas tentang pemilihan Presiden, Legislatif, khususnya pemilihan Kepala Daerah di Papua menggunakan sistem noken. Selanjutnya terkait bentuk pendidikan politik melalui noken bagi masyarakat Papua. Hal ini penting untuk dikaji, mengingat bahwa Papua merupakan wilayah yang memiliki karakteristik khusus dibanding
\end{abstract}


dengan daerah lain. Jenis penelitian menggunakan penelitian doktrinal, dengan pendekatan yuridis normatif. Pilihan metode menggunakan pola berfikir deduktif, paradigma positifisme kemudian dianalisis dengan deskriptif presprektif. Hasil dari kajian ini adalah pertama, penerapan penggunaan noken di Papua dalam Pemilihan Kepala Daerah menggunakan dua sistem yaitu noken bigmen dan noken gantung. Noken bigmen artinya seluruh suara diserahkan atau diwakilkan kepada ketua adat. Sedangkan noken gantung warga dapat melihat kesepakatan dan ketetapan suara. Kedua, bentuk pendidikan politik melalui penggunaan sistem noken yaitu adanya musyawarah dalam mufakat untuk menentukan seorang pemimpin. Rakyat sepenuhnya percaya kepada ketua suku, siapa calon yang dianggap baik dan layak dipilih. Musyawarah untuk mufakat merupakan penjelmaan Pancasila sila ke empat.

Kata Kunci: noken; Papua; pendidikan politik.

\section{PENDAHULUAN}

Demokrasi di Indonesia berbeda dengan demokrasi barat. Demokrasi barat merupakan demokrasi liberal atau bebas. Demokrasi di Indonesia dibangun dari Pancasila, sebagai fundamental norma yang dijabarkan pada norma peraturan perundang-undangan. Demokrasi yang dianut oleh negara Indonesia berasal dari UUD NRI Tahun 1945. Pembukaan UUD NRI Tahun 1945 ditegaskan mengenai tujuan negara republik Indonesia yaitu "untuk memajukaan kesejahteraan umum, mencerdaskan kehidupan bangsa, dan ikut melaksanakan ketertiban dunia yang berdasarkan kemerdekaan, perdamaian abadi dan keadilan sosial". Diharapkan dengan demokrasi, tujuan negara bisa terwujud. Salah satu wujud demokrasi yaitu dilaksanakanya pemilu.

Pemilu merupakan sebuah ritual dalam memilih seorang pemimpin. Pemilu yang dilaksanakan oleh negara Indonesia dalam rangka mewujudkan kedaulatan rakyat sekaligus penerapan prinsip-prinsip atau nilai-nilai demokrasi, meningkatkan kesadaran politik rakyat untuk berpartisipasi aktif dalam pemilihan umum demi terwujudnya cita-cita masyarakat Indonesia yang demokratis. Ini berarti bahwa pada 
pelaksanaan pemilu yang demokratis menekankan terjadinya pergantian secara periodik (regular election). Pemilu juga untuk menentukan dan memilih siapa-siapa saja yang pantas yang akan mewakili rakyat dan juga untuk memilih pemimpin yang akan memimpin dan membawa negera ke arah yang lebih baik. Pemilu dianggap sebagai tolok ukur utama dan pertama dari demokrasi. ini dikarenakan pemilu memang dianggap akan melahirkan suatu representatif aspirasi rakyat yang tentu saja berhubungan erat dengan legitimasi bagi pemerintah.

Pemilu sering disebut sebagai ajang pesta demokrasi rakyat yang menjadi cermin ikut andilnya rakyat dalam menentukan pemimpin dan arah perkembangan bangsa. Namun pada perkembangannya pemilu di Indonesia masih banyak kekurangannya dan menjadi pekerjaan rumah yang perlu diperbaiki bersama. ${ }^{1}$

Konteks Indonesia, demokrasi di tataran lokal (daerah), sebagai suatu konsekuensi dari pelaksanaan desentralisasi politik. ${ }^{2}$ Wujud dari proses desentralisasi adalah pelaksanaan pemilihan kepala daerah (Pilkada) untuk memilih Gubernur/Wakil Gubernur, Bupati/Wakil Bupati, Walikota/Wakil Wali Kota Sebagai pelaksanaan dari amanat Undang Undang Nomor 32 Tahun 2004 tentang Pemerintahan Daerah. ${ }^{3}$ salah satunya yaitu Pelaksanaan Pemilihan Kepala Daerah (Pilkada)

\footnotetext{
1 Anies Prima Dewi, \& Idea Islami Parasatya, Hak Memilih Penyandang Disabilitas Mental dalam Pemilihan Umum Serentak tahun 2019 di Indonesia, Media keadilan: Jurnal Ilmu Hukum, Volume 10 Nomor 1, April, 2019, hlm 101, DOI: https://doi.org/10.31764/jmk.v10i1.1108, Url: http://journal.ummat.ac.id/index.php/JMK/article/view/1108.

2 Fauzi. Perselisihan pemilukada, demokrasi lokal-evaluasi pemilukada di Indonesia. Konstitusi press/ konpress. Jakarta. 2012. Hlm 31

3 Undang Undang Nomor 32 Tahun 2004 tentang Pemerintahan Daerah, Lembaran Negara RI Tahun 2004 Nomor 125, Tambahan Lembaran Negara Republik Indonesia Nomor 4437.
} 
Papua yang menggunakan sistem Noken. ${ }^{4}$ Sistem noken merupakan tradisi masyarakat adat Papua di wilayah pegunungan tengah. ${ }^{5}$

Pada petunjuk teknis (Juknis) KPU Papua Nomor 1 tahun 2013 noken digunakan sebagai pengganti kotak suara, disisi lain noken juga dikenal sebagai sistem pemberian suara dalam pemilu di bumi cendrawasih, sistem noken ini bahkan sudah dikenal sejak masa referendum, jajak pendapat, atau disebut sebagai Perpera pada 1969 di Irian Barat, sebelum namanya berganti menjadi Irian dan Papua kini. Sistem noken adalah pemberian suara melalui perwakilan oleh kepala suku atas kesepakatan warga di kampung tertentu.

Cara pemungutan suara dengan sistem noken sudah lama diakui Mahkamah Konstitusi (MK) sebagaimana dituangkan dalam putusan MK No. 47-81/PHPU-A-VII/2009. Dalam pertimbangannya MK menyatakan: "Menimbang bahwa Mahkamah dapat memahami dan menghargai nilai budaya yang hidup di kalangan masyarakat Papua yang khas dalam menyelenggarakan pemilihan umum dengan cara atau sistem 'kesepakatan warga' atau aklamasi. Mahkamah menerima cara pemilihan kolektif (kesepakatan warga atau aklamasi) yang telah diterima masyarakat Kabupaten Yahukimo tersebut karena jika dipaksakan pemilihan umum sesuai dengan peraturan perundang-undangan yang berlaku dikhawatirkan akan timbul konflik di antara kelompok-kelompok masyarakat setempat".

Pentingnya sistem noken yang dilaksanakan pada pemilihan di Papua dan untuk mendapatkan pemahaman yang kompleks sehingga pada kajian ini perlu adanya pembahasan lebih mendalam mengenai Bagaimana penggunaan noken di Papua dalam pemilihan Kepala Daerah dan bagaimana bentuk pendidikan politik melalui noken bagi masyarakat Papua.

\footnotetext{
${ }^{4}$ Noken adalah istilah yang biasa dipakai untuk menyebut sejenis kantung atau tas yang biasa dipakai masyarakat Papua untuk membawa sayuran atau ayunan bayi. Biasa juga dipakai untuk menyimpan surat-surat.

${ }^{5}$ Mulyani, T., Nuswanto, A. H., \& Sukimin, S. Sistem Noken Di Provinsi Papua: Studi Putusan MK Nomor 47-81/PHPU.A-VII/2009. Jurnal Ius Constituendum, 2020. https://doi.org/10.26623/jic.v5i1.2219.
} 


\section{METODOLOGI}

Jenis penelitian yang digunakan adalah ranah kajian doktrinal. Penelitian ini termasuk dalam kategori penelitian normatif dengan pendekatan yuridis normatif melalui metode berfikir deduktif. ${ }^{6}$ Pendekatan yuridis normatif yaitu memandang hukum sebagai sistem peraturan peraturan yang abstrak, tersusun secara logis, sistematis dalam suatu UndangUndang sehingga siap untuk diterapkan. ${ }^{7}$ sedangkan berfikir secara deduktif yaitu berfikir yang diawali dari sebuah norma/aturan.

\section{PEMBAHASAN}

\section{A. Penggunaan Noken di Papua dalam Pemilihan}

Sistem noken adalah suatu sistem yang digunakan dalam Pemilu khusus untuk wilayah provinsi Papua. Oleh Komisi Pemilihan Umum (KPU), noken menjadi bagian penting dalam pelaksanaan pilkada Papua, khususnya untuk masyarakat Papua yang berasal dari daerah pegunungan. ${ }^{8}$ Sistem noken berkaitan langsung dengan para pemimpin tradisional. Pada pelaksanaan sistem noken Ada dua cara yang digunakan dalam sistem noken, yakni noken bigmen dan noken gantung. Noken bigmen artinya seluruh suara diserahkan atau diwakilkan kepada ketua adat. Tipe ini terjadi pada masyarakat Pegunungan Tengah yang dalam antropologi disebut tipe bigman, dalam bahasa lokal menagawan, artinya lebih kurang 'orang berwibawa'. Orang berwibawa meraih status sebagai pemimpin bukan karena warisan. Ini adalah pencapaian status, yang diraih atas dasar perilaku, tindakan, dan usaha memenangkan persaingan dengan orang-orang lain atau lawan yang

\footnotetext{
${ }^{6}$ Arif Hidayyat. Kebebasan Berserikat di Indonesia (Analisis Pengaruh Perubahan Sistem Politik terhadap Penafsiran Hukum). Badan penerbit Universitas Diponegoro. Semarang. 2006. hlm. 52

7Yusriyadi, Tebaran Pemikiran Kritis Hukum dan Masyarakat, Surya Pena Gemilang Publishing-cet 2, Malang, 2010, hlm. 19

${ }^{8}$ https://id.wikipedia.org/wiki/Sistem_noken diakses pada tanggal 2 Juni 2018.
} 
menjadi pesaing. Di Papua, seorang pemimpin di sebuah kampung belum tentu dianggap pemimpin di kampung lain. Seorang pemimpin lintas kampung adalah pemimpin yang mampu berdiplomasi dengan pemimpin kampung lain dan menjalin persekutuan, menghormati wewenang, dan pantang mempermalukan pemimpin lain. Kepiawaian diplomasi serta membina persekutuan menjadikan seorang bigman disegani oleh beberapa bigman lain. Untuk sistem pemilihan cara bigman untuk lebih jelasnya bisa dilihat di bagan berikut:

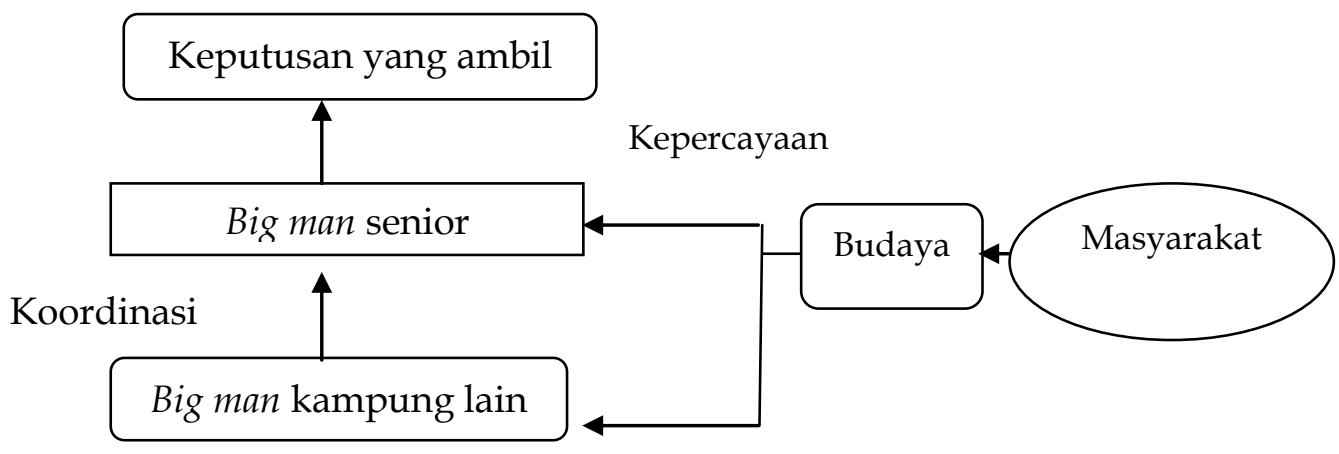

Gambar 1. Sistem Pemilihan Cara Bigman

Sedangkan pada noken gantung, warga dapat melihat kesepakatan dan ketetapan suara. Sistem pemilihan noken merupakan simbol musyawarah tertinggi untuk penentuan pendapat di Papua tanpa rahasia dan lebih mementingkan musyawarah di dalam suku. Dalam kedua jenis sistem noken, prinsip bebas dan rahasia tidak berlaku. Dalam pola bigman, warga sepenuhnya menyerahkan pilihan kepada pemimpin sebagai ekspresi ketaatan. ${ }^{9}$ Pemilu sistem noken pertama kali dilaksanakan tahun 2004 di 16 kabupaten di Provinsi Papua. Beberapa alasan dilangsungkan pemilu noken;

Pertama, geografis. Jarak tempuh untuk mendistribusikan logistik pemilu dan tingkat kesulitan medan di daerah pedalaman Papua dinilai sangat rumit untuk diakses secara cepat. Topografi daerah dengan

\footnotetext{
${ }^{9}$ https://nasional.kompas.com/read/2014/08/18/08011511/Sistem.Noken.dan.Bigman..
} 
mayoritas bergunung terjal dan jurang tajam dan terbatasnya akses akses transportasi, hanya dapat menggunakan pesawat berbadan kecil/pesawat misionaris, sehingga akan berdampak pada inskonsitensi agenda pemilu nasional, terutama bagi penyelenggara saat itu.

Kedua, sumber daya manusia (SDM), dengan pertimbangan bahwa sebagian masyarakat di wilayah pegunungan belum tersentuh pendidikan, masyarakat di kampung-kampung masih hidup secara komunal dan tradisional, belum memahami pemilu secara valid tentang maksud dan tujuan serta manfaat sehingga mereka perlu dituntun dan diarahkan melalui sebuah proses musyawarah bersama mengambil keputusan dalam memilih.

Ketiga, sosial budaya. Faktor ketiga yang menjadi acuan paten adanya pemilu noken di Papua adalah sosial budaya. Secara sosialbudaya, masyarakat di pedalaman Papua menganut sistem politik tradisional yang dikenal dengan bigman (orang besar). Setiap keputusan dalam komunitas dilaksanakan secara kolektif kolegial, misalnya ketika suatu hal yang hendak dilaksanakan baik dalam kehidupan dan berkaitan dengan hubungan sosial kemasyarakatan, masyarakat akan berkumpul dan bermusyawarah kemudian setiap ide dan gagasan dalam musyawarah tersebut dapat diakumulasi menjadi keputusan mutlak dan dinyatakan secara resmi oleh kepala suku (big man) mereka. Faktor ini saat itu dinilai sangat relevan untuk diadopsi ke dalam sebuah regulasi untuk menetapkan pemilihan noken menjadi sah.

Ketiga faktor di atas memiliki kontribusi yang sangat positif untuk keluarnya keputusan MK dengan nomor 47-81/PHPU-A-VII/ 2009 tentang Pemilu Sistem Noken di Papua, dengan dalih MK memahami dan menghargai nilai budaya yang hidup di kalangan masyarakat Papua yang khas dalam pemilu dengan cara (sistem) "kesepakatan warga" atau aklamasi tetapi kemudian MK membatasinya untuk tidak dilakukan di 
daerah lain yang tidak melakukan sistem noken. Aturan MK ini baru keluar pada tahun 2009. Sistem noken sering dimultitafsirkan oleh masyarakat, sebagian masyarakat memahami bahwa sistem noken adalah perubahan objek yaitu wujud kotak suara KPU yang diganti dengan wujud noken kemudian digantung ketika pemilihan sedang berlangsung, noken yang digantung itu bertujuan sebagai pengganti kotak suara untuk mengisi surat suara di dalamnya, adalah pula yang beranggapan bahwa sistem noken mengandung makna filosofis, yakni membuka, mengisi dan mengikat. Dalam tradisi kehidupan masyarakat pegunungan Papua noken adalah salah satu objek budaya yang tak dapat dipisahkan dalam kehidupan rutinitas masyarakat, kemudian hal tersebut dimaknai dalam nilai pemilu dengan membuat komitmen politik, kesepakatan bersama dan memberikan secara utuh suara (dukungan) kepada calon tertentu dengan musyawarah mufakat bersama. ${ }^{10}$

Dari 29 kabupaten/kota di Papua, ada 13 daerah yang mempraktekan sistem noken. Ada dua mekanisme penggunaan sistem noken. Pertama, penggunaan noken untuk menggantikan kotak suara. Surat suara diletakkan di dalam tas noken yang biasanya dipegang oleh para saksi dari pasangan calon. Kedua, sistem noken di mana kepala suku memilih untuk dan atas nama pemilih di kelompok sukunya. Kedua mekanisme ini sama-sama tidak bersifat rahasia. Maka pemilihan melalui sistem noken merupakan pemilihan yang tidak langsung/rahasia, di mana satu orang-satu suara-satu nilai. Tetapi, pemilihan konsensus yang biasanya berdasarkan kesepakatan atau keputusan bersama di suatu suku yang diwakili melalui kepala suku.

\footnotetext{
http:/ / tabloidjubi.com/m/artikel-16430-pemilu-yang-berkualitas-dan-sistem-noken-diPapua.html
} 


\section{B. Bentuk Pendidikan Politik Melalui Noken bagi Masyarakat Papua}

Pada hakikatnya pemilihan umum, di negara manapun mempunyai esensi yang sama. Pemilu, berarti rakyat melakukan kegiatan memilih orang atau sekelompok orang menjadi pemimpin rakyat atau pemimpin negara (untuk selanjutnya disebut pemimpin negara dan tidak dibedakan untuk sementara dengan pemimpin pemerintah). Pemimpin yang dipilih itu akan menjalankan kehendak rakyat yang memilihnya. ${ }^{11}$ Hakikat dari seorang pemimpin yaitu manivestasi dari rakyat dan dipergunakan untuk rakyat. Pemaham itu dikenal demokrasi yang memiliki makna dari rakyat, oleh rakyat dan untuk rakyat. Sebegitu pentingnya aspirasiakyat maka perlu digunakan sebuah sistem yang menjamin suara rakyat (keinginan) tersalurkan.

Dari sudut pandang Hukum Tata Negara, pemilihan umum merupakan proses politik dalam kehidupan ketatanegaraan sebagai sarana menunjuk pembentukan lembaga-lembaga perwakilan yang mengemban amanat rakyat. Menurut Sri Soemantri, Pemilu yang dilaksanakan harus merupakan pemilihan umum yang bebas, sebagai syarat mutlak bagi berlakunya demokrasi, dan dapat dihubungkan dengan kenyataan dimana nilai suatu pemerintahan untuk sebagian besar bergantung kepada orang-orang yang duduk di dalamnya. Hal ini perlu juga harus diyakini bahwa pemilu adalah bentuk partisipasi politik rakyat atau warga negara yang paling dasar untuk menentukan pemerintahan dan program yang sesuai dengan keinginannya, paling tidak pemerintah atau program yang dapat diterimanya. ${ }^{12}$

Sejatinya pelaksanaan pemilihan Kepala daerah baik itu langsung maupun tidak langsung merupakan demokrasi yang berdasar pada Pasal

\footnotetext{
11 Parulian Donald, Menggugat Pemilu, Pustaka Sinar Harapan, Jakarta: 1997, hlm.4

12 Sodikin, Hukum Pemilu, Pemilu Sebagai Praktek Ketatanegaraan, Gramata Publishing, Bekasi: 2014. Hlm. 2
} 
18 Ayat (4) UUD NRI Tahun 1945. Pada pelaksanaan noken dalam Pemilihan Kepala Daerah di Papua merupakan salah satu pelaksanaan demokrasi yang dilaksanakan berdasar adat istiadat dan kebudayaan masyarakat Papua (local wisdom).

Dalam Konsep pendidikan politik tampak bahwa pembentukan suatu sikap atau perubahan perilaku tidak dapat dilakukan secara mendadak atau sekaligus, akan tetapi dilakukan melalui suatu proses yang relatif lama yaitu proses pendidikan (educational process). Pendidikan mengaktifkan unsur unsur dinamis dalam artian tidak hanya membentuk dan mengubah sikap dan perilaku, tetapi juga menanamkan tata nilai dan membentuk pola pikir sistimatis dan argumentatif didalam memandang problem yang dihadapi. Dalam hal ini masyarakat Papua tidak hanya melaksanakan demokrasi tetapi menerapkan nilai nilai Pancasila khususnya sila ke-empat yang intinyaa"musyawarah mufakat".

Tidak hanya itu, Pendidikan politik sangat berperan penting untuk mewujudkan kehidupan yang demokratis. Kehidupan yang demokratis tidak hanya memerlukan peraturan perundang-undangan yang rigid, melainkan memerlukan sikap yang demokratis. Termasuk sikap untuk mengakui kekalahan, bersedia untuk bekerjasama dengan kelompok lain untuk membentuk tatanan pemerintahan yang stabil demi kehidupan yang adil sejahtera dan sentosa. Sehingga salah satu peran penting adanya pendidikan politik terhadap pemilih khususnya masyarakat Papua adalah untuk mewujudkan kehidupan masyarakat yang demokratis, yaitu sebagai warga masyarakat yang berfikir secara kritis, dan bertindak demokratis melalui aktivitas menanamkan kepada pemilih pada tiga hal, di antaranya pertama, demokrasi adalah bentuk kehidupan bermasyarakat yang menjamin hak-hak warga Negara masyarakat itu sendiri. Kedua, demokrasi adalah suatu learning process yang tidak dapat begitu saja meniru dari masyarakat lain. Ketiga, kelangsungan demokrasi tergantung 
pada keberhasilan mentransformasikan nilai-nilai demokrasi: kebebasan, persamaan dan keadilan serta loyal pada sisitem politik yang bersifat demokratis ${ }^{13}$.

Masyarakat Papua ketika menggunakan noken pada pemilihan maka secara tidak langsung, maka masyarakat Papua telah menerapkan nilai nilai pancasila khususnya sila ke empat yaitu musyawarah mufakat serta demokrasi tidak langsung. Demokrasi tidak langsung juga bagian dari Pasal 18 (4) UUD NRI Tahun 1945.14 Tidak hanya belajar berdemokrasi, tetapi masyarakat Papua juga percaya kepada ketua suku ini artinya bahwa masyarakat Papua juga ingin mempertahankan dan menjaga kebudayaan dari leluhur. Mengingat bahwa percaya kepada kepala suku merupakan budaya leluhur Papua. Maka sesungguhnya banyak pelajaran/pendidikan dari masyarakat Papua yang tentunya dari hal hal tersebut pemerintah dan masyarakat Papua bisa mengevaluasi kekuranga dan kelebihannya dan menjadikan kemajuan Papua lebih baik.

Hal tersebut diketahui dari pemilihan yang dilaksanakan secara transparan atas dasar kesepakatan bersama yang merangkum keputusan pribadi para pemilih. Pencoblosan surat suara bisa dibuat tempat pemungutan suara atau di kantor kecamatan, tetapi hasilnya mesti sesuai dengan kesepakatan rakyat. Jadi, tidak ada rakyat yang memberontak ketika pemungutan suara tidak dilaksanakan di tempat pemungutan suara. Pemungutan suara tidak harus dihadiri semua pemilih karena pencoblosan dapat dilakukan orang yang mewakili mereka. Rakyat tidak menyuruh tokoh adat atau kepala suku melakukan pencoblosan, bukan karena tidak percaya, tetapi karena menghormatinya. Biasanya rakyat

13 Zamroni, Pendidikan Tantangan Menuju untuk Demokrasi (Civil Society). Bigraf Publishing. Jakarta. 2000.

14 Sodikin, S. Pemilihan Kepala Daerah dalam Konteks UUD NRI tahun 1945. Jurnal Rechts Vinding: Media Pembinaan Hukum Nasional. 2015, https://doi.org/10.33331/rechtsvinding.v4i1.47. 
meminta tolong kepada orang yang mereka percayai, entah salah satu di antara mereka, entah bahkan penyelenggara pemilu, untuk melakukan pencoblosan sesuai dengan kesepakatan rakyat.

\section{SIMPULAN}

Penggunaan noken di Papua dalam pemilihan merupakan sebuah konsep sistem pemilihan yang memberikan keputusan kepada ketua suku. Hal ini mengingat bahwa Papua merupakan daerah yang memiliki kekhasan budaya. Menurut putusan MK nomor 47-81/PHPU.A-VI/2009, sistem noken disahkan sebagai budaya asli Papua. Berdasar pada penggunaan noken di Papua merupakan bagian dari representatif dari nilai nilai demokrasi yang telah tertuang dalam Pasal 18 (4) UUD NRI Tahun 1945. Tentunya pada penerapanya masih banyak adanya kekurangan dalam sistem noken, maka perlu adanya sinergi antara pemerintah, masyarakat Papua, calon pemimpin berintegritas, sehingga segala persoalan akan mudah di selesaikan. Adapun Pendidikan politik melalui noken bagi masyarakat Papua, pemilihan dilaksanakan secara transparan atas dasar kesepakatan bersama yang merangkum keputusan pribadi para pemilih. Oleh karena itu, rakyat tidak mempermasalahkan tempat pemungutan suara. Kesepakatan rakyat yang disimbolkan melalui noken mencerminkan partisipasi dan emansipasi politik. Rakyat telah menyatakan kedaulatannya dalam memilih calon pemimpin yang dipercayainya. Seiring hal tersebut maka harus dibarengi dengan peningkatan Sumber Daya Manusia. Karena dengan adanya sumber Daya Manusia yang berkualitas maka akan bisa melengkapi sistem noken yang telah diterapkan di Papua. 


\section{REFERENSI}

\section{A. Buku}

Fauzi, 2012, Perselisihan Pemilukada, Demokrasi Lokal-Evaluasi Pemilukada di Indonesia, Konstitusi Press/ Konpress, Jakarta.

Hidayat, Arif, 2006, Kebebasan Berserikat di Indonesia (Analisis Penaruh Perubahan Sistem Politik Terrhadap Penafsiran Hukum). Badan penrbit Universitas Diponegoro, Semarang.

Parulian Donald, 1997, Menggugat Pemilu, Pustaka Sinar Harapan, Jakarta. Sodikin, 2014, Hukum Pemilu, Pemilu Sebagai Praktek Ketatanegaraan, Gramata Publishing, Bekasi.

Yusriyadi, 2010, Tebaran Pemikiran Kritis Hukum dan Masyarakat, Surya Pena Gemilang Publishing-cet 2, Malang.

Zamroni, 2000, Pendidikan Tantangan Menuju untuk Demokrasi (Civil Society). Bigraf Publishing, Jakarta.

\section{B. Jurnal dan Makalah}

Anies Prima Dewi, \& Idea Islami Parasatya, 2019, Hak Memilih Penyandang Disabilitas Mental dalam Pemilihan Umum Serentak tahun 2019 di Indonesia, Media keadilan: Jurnal Ilmu Hukum, Volume 10 Nomor 1, April, hlm 101, DOI: https://doi.org/10.31764/jmk.v10i1.1108, Url: http://journal.ummat.ac.id/index.php/JMK/article/vie $\underline{\mathrm{w} / 1108}$.

Mulyani, T., Nuswanto, A. H., \& Sukimin, S. 2020, Sistem Noken Di Provinsi Papua: Studi Putusan MK Nomor 4781/PHPU.A-VII/2009. Jurnal Ius Constituendum. https://doi.org/10.26623/jic.v5i1.2219. 
Sodikin, S. 2015. Pemilihan Kepala Daerah dalam Konteks UUD NRI tahun 1945. Jurnal Rechts Vinding: Media Pembinaan Hukum Nasional. https://doi.org/10.33331/rechtsvinding.v4i1.47.

\section{Undang-Undang}

Undang Undang Nomor 32 Tahun 2004 tentang Pemerintahan Daerah, Lembaran Negara RI Tahun 2004 Nomor 125, Tambahan Lembaran Negara Republik Indonesia Nomor 4437.

putusan MK nomor 47-81/PHPU.A-VI/ 2009

D. Website

http:/ / tabloidjubi.com/m/artikel-16430-pemilu-yang-berkualitas-dansistem-noken-di-Papua.html diakses pada tanggal 2 Juni 2020

https://id.wikipedia.org/wiki/Sistem_noken diakses pada tanggal 2 Juni 2020

https://nasional.kompas.com/read/2014/08/18/08011511/Sistem.Noke

n.dan.Bigman diakses pada tanggal 2 Juni 2020. 